\title{
Interactive comment on "Equatorward
} \section{phytoplankton migration during a cold spell within the Late Cretaceous supergreenhouse" by Niels A.G.M. van Helmond et al.}

\author{
P. Schioler (Referee) \\ poul.schioler@mgpalaeo.com.au
}

Received and published: 14 March 2016

The ms presents new data and compiles existing data on the Plenus Cold Event at the Cenomanian-Turonian boundary and shows that the Ccm Complex of dinoflagellates migrated towards the Equator during the cold event. It thereby shows that yet another group of dinoflagellates responded to temperature changes by migrating. This is an important observation because it elucidates how environmental factors need to be taken into consideration when biostratigraphic interpretations and correlations are made and also indicates how certain plankton groups can be used as proxies for temperature changes in the far past. The ms is very well written in clear language. It is brief and concise and makes it point without any irrelevant ado. The illustrations are informative, 
of good quality and well captioned. I have seen this manuscript before and notice that all my previous comments and suggestions to changes hav been taken on-board, and I therefore believe that the ms should be published in Biogeosciences as is.

Interactive comment on Biogeosciences Discuss., doi:10.5194/bg-2015-659, 2016. 